logos_i_ethos_2015_1_(38), s. 7-24

DOI: http://dx.doi.org/10.15633/lie.1042

\author{
Damian Michałowski \\ Uniwersytet Przyrodniczy w Poznaniu
}

\title{
Ambiwalencja i Tajemnica. Wokół antropologii filozoficznej Dostojewskiego
}

Chcąc uniknąć nieporozumień, zacznijmy od kwestii metody. Zaskakująco brzmi bowiem to, co o Dostojewskim pisze Orhan $\mathrm{Pa}$ muk: „Czytamy Dostojewskiego,

Damian Michałowski - doktor filozofii, absolwent filozofii i polonistyki Uniwersytetu Wrocławskiego, adiunkt w Katedrze Nauk Społecznych Uniwersytetu Przyrodniczego w Poznaniu. aby zrozumieć jego bohaterów, a nie samo życie. Lektura wielkiej powieści, jaką są Bracia Karamazow, staje się medytacją nad czterema różnymi postaciami i typami charakterów: Iwana, Aloszy, Dymitra i ich przyrodniego brata Smierdiakowa. Refleksja nad nimi pochłania nas całkowicie, ale jednocześnie nie potrafimy oprzeć się wrażeniu, że prawdziwe życie wygląda jednak inaczej"1.

Czyżby? Czytamy Dostojewskiego właśnie po to, by zrozumieć życie. Czytamy nie dla pustej rozrywki, lecz po to, by współ-doświadczać i współ-myśleć, a przez to lepiej rozumieć świat i ludzkie w nim uczestnictwo. Wszystkie dylematy filozofii metafizycznej - od zagadki człowieka i jego egzystencji poprzez miłość, cierpienie, śmierć i zło, na sumieniu i Bogu kończąc - to tematy, nad którymi Dostojewski wciąż rozmyśla i do rozmyślania nad którymi zaprasza nas. Lektura powieści jest zaś dlatego tak pochłaniająca, że bohaterowie, których meandry losu czytelnik śledzi z zaciekawieniem, nie mają nic z postaci papierowych, przeciwnie: są realni i jako tacy ukazują całą złożoność i wieloaspektowość ludzkiego bytu. Każdy, kto czyta Dostojewskiego, zostaje porażony miarą przenikliwości, z jaką patrzy on na istotę ludzką. Niczym 
wytrawny psychoanalityk śledzi Dostojewski zagadkowość ludzkiego wnętrza i wszelkie jego tajemnice, nieustanne przeplatanie świadomego i nieświadomego, procesy samozakłamania i samooszustwa, a także trudną drogę dochodzenia do siebie samego, do prawdy o swoim najgłębszym „Ja”.

Czy prawdziwe życie wygląda inaczej? Być może gdybyśmy byli wstanie słyszeć ludzkie myśli i widzieć zakryte intencje działan - co Dostojewski, jak się zdaje, w dużej części potrafił - odpowiedź byłaby w sposób oczywisty negatywna. „Nierealność” świata, z jakim mamy do czynienia w Idiocie lub Biesach, polega wyłącznie na tym, że oprócz oglądu behawioralnego mamy do czynienia także z psychoanalitycznym, widzimy bowiem nie tylko zachowania, ale i motywy. Po wtóre, rozrzedzony przez codzienną krzątaninę świat ludzkiego ducha u Dostojewskiego ukazany jest w esencji i zagęszczeniu. Metoda pisarza polega na tym, by - niczym w fenomenologicznej redukcji - ująć samą istotę rzeczy. Stanisław Mackiewicz-Cat, z właściwą sobie plastycznością języka i temperamentem, pisze, że swą psychologiczną analizę Dostojewski uprawia jakby za pomocą powiększającego szkła: tak bowiem jak oko muchy w mikroskopie staje się podobne do wulkanicznego krateru, tak ciche i zatajone uczucie ludzkie oglądane z bliska przez przenikliwego obserwatora staje się rozpaczą i krzykiem ${ }^{2}$. Nie ma tu nierealności, jest tylko zmiana pozycji obserwatora, który dzięki metodzie (powiększenie, zwolnienie, przesadnia, hiperbolizacja) widzi to, co w normalnych warunkach niedostrzegalne: „Kiedy w kinie, w zdjęciach sportowych, stosują zwolnienie tempa i patrzymy na konia, który unosi się nad przeszkodą w posuwistym tempie przypominając nam ruchy powolnej ryby, to również mamy do czynienia z metodą fantastyczną, nienaturalną, zastosowana nam dla ułatwienia obserwacji, dla wytłumaczenia tajemnic końskiego skoku, ale metodą dającą nam obraz nieistniejący w rzeczywistości i dziwaczny"3.

Logika i potrzeba porządku $\mathrm{z}$ jednej strony, $\mathrm{z}$ drugiej zaś myślenie powierzchowne i stereotypowe, do któregośmy przywykli, powodują, że

\footnotetext{
Zob. S. Mackiewicz-Cat, Dostojewski, Bielsko-Biała 1997, s. 10.
}

Tamże, s. 11 . 
świat rosyjskiego pisarza wydaje się nierealny: wygodniej i bezpieczniej jest patrzeć na wszystko poprzez gotową matrycę standardów i norm. Na to Dostojewski się jednak nie zgadza. Podobnie jak Nietzsche, odrzuca on jedność i prymat świadomości, ukazując kłębowisko woli i żądz, emocji i instynktów, namiętności i kompleksów. Podobnie jak Bergson, odrzuca ontologiczne uporządkowanie, ukazując, że byt - również byt ludzki - jest chaosem.

\section{Dychotomizmy}

Istotę ambiwalencji wyraża Karamazowszczyzna. Karamazowską duszę opisuje zaś trafnie wiceprokurator Hipolit Kiryłowicz, mówiąc o Dymitrze: „Zazwyczaj w życiu bywa tak, że mając dwie przeciwne sobie rzeczy, szuka się prawdy pośrodku; w obecnym wypadku regula ta nie znajduje potwierdzenia. Prawdopodobnie w pierwszym wypadku był szczerze szlachetny, a w drugim równie szczerze podły. Dlaczego? Dlatego że jest szeroką naturą, karamazowską - wszak do tego zmierzam - naturą, która mieści w sobie wszelkie krańcowości i jednocześnie zdolna jest kontemplować obie otchłanie: otchłań wzniosłych ideałów, otchłań nad nami, i otchłań pod nami, otchłań najniższego i cuchnącego upadku"4.

Jakkolwiek myśl, że ambiwalencja jest atrybutywną cechą człowieka, nie jest nowa i, naturalnie, nie Dostojewski jest jej autorem (antecedencje sięgają Sofoklesa, Pawła z Tarsu, św. Augustyna, Pascala i romantyków), to właśnie u Dostojewskiego przybiera ona formę wyjątkową. Biorąc rzecz ogólnie, ambiwalencja istoty ludzkiej oznacza niespójność jej pragnień, rozbieżność tęsknot i brak konsekwencji zachowań, które podejmuje ona pod wpływem zmiennych impulsów emocji, przebiegających - z istoty - wahadłowo, po biegunach. U Dostojewskiego szczególna jest ostrość tych dychotomizmów. Jego bohaterowie są rozedrgani do granic możliwości. Wokół panuje jakiś niezrozumiały bałagan i szamotanie się. Wszystko wrze, gotuje się i wzrasta w swym ciśnieniu 
gotowe do prawdziwej eksplozji niepohamowanych parkosyzmów. Istotnie, człowiek jest tu kipiącym tyglem niedorzecznych sprzeczności - sprzeczności ze sobą wymieszanych i współwystępujących; przede wszystkim zaś zupełnie nieostrych w swym ontologiczno-etycznym amorfizmie. Coincidentia oppositorum nie ma więc nic ze spokoju, jest raczej niekończącym ścieraniem się heteronomicznych elementów, ich przybliżaniem i oddalaniem, chwilową zgodą, sprzecznością i ustępowaniem sobie miejsca, niemal jak w kosmologicznej wizji starego Empedoklesa. Chaos nie prowadzi jednak do harmonii. Bohaterowie powieści z zawrotną prędkością pędzą bowiem w konwulsjach i szarpaninie ku jakimś niezrozumiałym zupełnie awanturom i, wyrzucając $z$ siebie sprzeczne emocje, pogrążają się w autodestrukcji.

Przykład. W urodzinowy wieczór Nastazja Filipowna ma oficjalnie odpowiedzieć, czy wyjdzie za Gawriłę Ardalionowicza (który chce ją poślubić interesownie, dla pieniędzy). Nieoczekiwanie zjawia się też książę Myszkin, za chwilę - Rogożyn. Pierwszy wyznaje miłość, drugi ofiarowuje paczkę stu tysięcy rubli (co też jest swoistym wyrazem miłości i chęcią „kupienia” żony). Wydarzenia, z początku spokojne, stają się coraz bardziej niedorzeczne. Ku zaskoczeniu wszystkich, nie mówiąc nic o małżeństwie, Nastazja decyduje się opuścić uroczystość z Rogożynem i jego pijaną bandą. Bierze jednak wcześniej sto tysięcy i zwraca się do Gawriły: „No to słuchajże, Gania, chcę po raz ostatni zobaczyć, jaką masz duszę; tyś mnie męczył całe trzy miesiące, teraz na mnie kolej"' I I wrzuca pieniądze do palącego się kominka - teraz należą do Gani, musi je tylko wyciągnąć z ognia gołymi rękoma. Nastazja patrzy z lubością. Wszystkich ogarnia przerażenie. Paczka pieniędzy zaczyna palić się coraz mocniej. Ktoś mówi: „zwariowała”, inny: „szalona”; „może by ją związać?”. Gania mdleje. „Sodoma i Gomora”. Nastazja wyciąga szczypcami paczkę rubli; opakowanie się nadpaliło, zawartość nie. „Cała paczka jego, wytrzymał, nie poszedł” - kładzie paczkę przy Gani, wraz z Rogożynem opuszcza towarzystwo. „Pójdę na ulicę, tam moje miejsce; albo będę praczką?”.

Tenże, Idiota, tł. J. Jędrzejewicz, Warszawa 1997, s. 197.

Tamże, s. 200. 
Oto Nastazja Filipowna: złożona, tajemnicza, intrygująca, piękna, niebezpieczna, straszna, niekonsekwentna, dwuznaczna, skomplikowana, poplątana, wykorzystana i skrzywdzona przez Tockiego, rozdarta pomiędzy Rogożynem i Myszkinem, tj. pomiędzy dobrem i złem, niebem i piekłem, zbawieniem i potępieniem. Tak właśnie Dostojewski szkicuje obraz ludzkiej natury. Dobro i zło, szlachetność i okrucieństwo, empatia i egoizm, szczerość i zakłamanie, wierność i zdrada, dystynkcja i prostactwo, szacunek i zazdrość, skromność i rozpusta, rozum i instynkt - wszystko się u Dostojewskiego łączy i przeplata. Czy jest tu jednak miejsce na to, by ta różnorodność została zintegrowana w ludzkiej osobie?

Zanim odpowiemy, zapytajmy o jedną jeszcze rzecz: Czym mianowicie miałby być ów integrujący rdzeń w człowieku? Lub inaczej: Jak wskazać i nazwać to miejsce, które - będąc zasadą osobowej tożsamości - scalałoby rozmaite aspekty egzystencji? Dla autora Biesów człowiek to nie tylko ambiwalencja, ale i tajemnica, co od razu utrudnia konkluzywną odpowiedź. Tajemnica jest bowiem niemożnością określenia ludzkiego eidos. Prawdę tę, obecną zarówno w prawosławnej teologii negatywnej, jak i współczesnej myśli Zachodu, zawiera formuła „wiem, że jestem, lecz nie wiem, kim jestem". Człowiek, owszem, jest podmiotem myśli i działań, on, nie kto inny, jest odpowiedzialny za etyczne wybory, w jego rękach leży zbawienie, a swego istnienia nie może zamienić z drugim. Gdzie jednak leży to osobowe ziarno odróżniające go od innych i jak to ziarno zdefiniować - odpowiedzieć jest bardzo trudno, gdyż intuicja nie przekłada się tu na dyskurs.

\section{Rosyjska dusza}

Przyjrzyjmy się jeszcze raz, dokładniej, problemowi niejednoznaczności natury ludzkiej i zapytajmy, o jaki jednak chaos tu chodzi i co dokładnie mamy na myśli, mówiąc „ambiwalencja”.

Posłużmy się najpierw kontrprzykładem. W Wilku stepowym Hermana Hessego główny bohater, Harry, ma dwie natury, ludzką i wilczą. Te dwie natury są jednak sobie całkiem obce. Żyją obok siebie, lecz 
nieustannie toczy się między nimi śmiertelna walka i - jak czytamy u Hessego - jedna natura żyje wyłącznie dzięki temu, że zadaje cierpienie drugiej. Gdy Harry jako człowiek spełnia dobry uczynek lub kieruje się delikatną myślą, wtedy wilk szczerzy kły i szyderczo się śmiejąc, pokazuje jak głupi, żenujący i próżny jest ten „szlachetny teatr”, jak puste i zakłamane jest zachowanie, które przedkłada maniery i obyczaje nad „samotną gonitwę po stepach”, „chłeptanie krwi” lub „uganianie się za wilczycą". I na odwrót: gdy Harry staje się wilkiem, człowiek, zatruwając mu radość czerpaną z wilczej natury, nazywa go bydlęciem i bestią ${ }^{7}$.

To antropologiczne rozszczepienie, podane jako kontrast wobec ambiwalencji u Dostojewskiego, nie jest oczywiście wersją jedyną. Pamiętamy ontologiczny dualizm Platona i Augustyna. Pamiętamy dobrze dylematy romantyków i ich nieustanne roztrząsanie, co w człowieku ważniejsze: rozum czy uczucie, nauka czy wiara. Historia literatury ukazuje też nie mniej istotny dychotomizm aksjologiczny (z którym mamy do czynienia, gdy bohater uwikłany jest w konflikt kontradyktorycznych wartości) oraz dualizm psychiczny, określany od jednej z bohaterek Flauberta mianem bowaryzmu, który oznacza kreowanie wyimaginowanej egzystencji i zapieranie się siebie po to, by stać się tym, kim chciałoby się być. Przypadek ostatni jest szczególny: osobowość wtórna, zaszczepia się na pierwotnej i zamienia się z nią rolami, główny dylemat polega jednak na nieustannym rozczarowaniu, wynikającym $\mathrm{z}$ dojmującego poczucia niezgodności pomiędzy obrazem „Ja” a rzeczywistością.

U Dostojewskiego - choć na pierwszy rzut oka wszystko wygląda podobnie - złożoność ludzkiej natury polega na czymś zgoła innym. André Gide mówi, że tym czymś jest symultaniczność ${ }^{8}$. Sprzeczne uczucia pojawiają się bowiem jednocześnie, a przynajmniej bardzo blisko siebie, jedne po drugich, naprzemiennie, w krótkich interwałach czasu. Stawrogin z Biesów wyraża to lapidarnie, lecz sugestywnie: „mogę spelnić dobry uczynek i daje mi to satysfakcję; zarazem chcę też złego i też 
czuję satysfakcję". Powiedzieć można jednak jeszcze więcej: sprzeczne uczucia jakby wzajemnie się definiują, żyją dzięki sobie i - paradoksalnie - wspierają się w istnieniu; nie widać tu krwawego antagonizmu, jak w Wilku stepowym, jest raczej jakaś przedziwna symbioza, wzajemne dopełnienie, jedno uczucie zostaje wyrażone poprzez swoje przeciwieństwo - choć wszystko wygląda bałaganiarsko, wręcz szaleńczo (czyż Rogożyn nie zamordował Nastazji, bardzo ją jednocześnie przy tym kochając?) Paradoks ten przedstawia sugestywnie Mackiewicz-Cat: „Jeśli Dostojewski tworzy typ skąpca, strasznego, bezgranicznego, apokaliptycznego skąpca, to ten skąpiec jest właśnie nam przedstawiony w chwili furii rozrzutności i marnotrawstwa. Jeśli Dostojewski tworzy typ nieustraszonego rycerza, to tylko dlatego, abyśmy zobaczyli, że rycerz nieustraszony może się zachować jak tchórz śmierdzący"10.

U Dostojewskiego jest więc tak: każde pragnienie, które się pojawia, po chwili traci wartość i znika po to, by ustąpić miejsca innemu, przeciwnemu, a bohaterowie zbliżają się do jakiegoś uczucia właśnie wtedy, gdy uczucie przeciwstawne odzywa się w nich najmocniej: są blisko miłości wtedy, kiedy następuje gwałtowny wybuch nienawiści, i na odwrót: zbliżają się do nienawiści wtedy, kiedy ich miłość wyraża się w sposób przesadny i wyolbrzymiony ${ }^{11}$. Ta symultaniczność jest u Dostojewskiego wręcz obsesyjna. Bachtin ujmuje to tak: „wszystko ujmować jako współistniejące, dostrzegać i ukazywać wszystko obok siebie równocześnie, jakby umieszczone tylko w przestrzeni, a nie w czasie"12.

Niezwykle w tym kontekście wygląda spotkanie dwóch kobiet z Braci Karamazow - Katarzyny Iwanowny i Gruszeńki. Spotykają się, by „rozstrzygnąć wszystko", tj. spór o Dymitra. Katarzyna Iwanowna, jakby zakochana w Gruszeńce, z entuzjazmem i zachwytem całuje ją kilkakrotnie w roześmiane wargi, nazywając aniołem, który sfruwając na ziemię, przyniósł pokój i radośćc ${ }^{13}$. Potem, znów w uniesieniu i egzaltacji, biorąc

\footnotetext{
$9 \quad$ F. Dostojewski, Biesy, tł. A. Pomorski, Kraków 2010, s. 673.

10 S. Mackiewicz-Cat, Dostojewski, dz. cyt., s. 12.

11 Por. A. Gide, Dostojewski, dz. cyt, s. 146.

12 M. Bachtin, Problemy poetyki Dostojewskiego, tł. N. Modzelewska, Warszawa 1970, s. 44.

13 Zob. F. Dostojewski, Bracia Karamazow, dz. cyt., t. 1, s. 210.
} 
dłoń Gruszeńki, mówi: „Ona mi szczęście przyniosła i wskrzesiła mnie, będę ją teraz całować, i z góry, i w dłoń, tak, tak i tak” i kilkakrotnie całuje „Śliczną, zbyt może pulchną" rączkę Gruszeńki. Już jednak po chwili sytuacja zmienia się biegunowo. Wbrew oczekiwaniom Katarzyny Iwanowny Gruszeńka oznajmia, że z Dymitra rezygnować nie zamierza. Następuje konsternacja. „Przedtem mówiła pani... zupełnie co innego”. - „Ach, przedtem. Serce mam delikatne, głupie”. I Gruszeńka, uniżając się niejako i przepraszając, w sposób „szczery i ufny” wychwala Katarzynę, podziwia jej dobroć i szlachetność, mówi, że będzie jej niewolnicą: „Wezmę ją, panienko miła, twoją rączkę, i pocałuję tak, jak pani pocałowała moją. Pani ją trzy razy pocałowała, a ja, żeby się skwitować, musiałabym ze trzysta razy pocałować". I nagle - zmienia zdanie. Nie, nie będzie całować rączki: „Niech to pani zachowa sobie na pamiątkę, że pani moją rączkę całowała, a ja pani nie”. Na co Katarzyna w odpowiedzi wykrzykuje: „Bezczelna”, „Łajdaczko, wynoś się!”, „To tygrysica”, „Zabiłabym ją”. „Taką to trzeba pod pręgierz, rózgami, publicznie, wobec wszystkich..."14.

Tak oto szacunek idzie w parze z pogardą, uznanie z niechęcią, miłość z nienawiścią: „rosyjska dusza” i tu znajduje swój wyraz. Szkicując obraz tej duszy, Bierdiajew używa metafory przestrzennej, porównując ją z jednej strony do rozległych obszarów Rosji (bezkres, bezmiar i nieskończoność, niemożność ogarnięcia, nieostrość granic i nieuchwytność), z drugiej wskazując na kulturowe i cywilizacje rozdarcie między Wschodem a Zachodem, tj. między kulturą kontemplatywną, ascetyczną i monastyczną (Azja) a kulturą pogańską i dionizyjską (Europa). „Geografia fizyczna” przekłada się na "geografię duchową" - tak bowiem jak nieogarnięty i rozdarty jest obszar Rosji, tak nieogarnięty i rozdarty jest obszar duszy. Zresztą, to niekomfortowe napięcie musi trwać: dominacja czynnika ascetyczno-monastycznego może prowadzić do nieuprawomocnionej absolutyzacji idei boskości w człowieku, dominacja siły dionizyjskiej - do idei nacjonalistycznych, rewolucyjnych i rebelianckich ${ }^{15}$.

14 Tamże, s. 214-215.

15 Zob. M. Bierdiajew, Rosyjska idea, tł. JC-SW, Warszawa 1987, s. 7-10; D. Jastrząb, Duchowy świat Dostojewskiego, Kraków 2009, s. 44-46. 
„Rosyjska dusza” jest nieprzenikniona i rozdarta; mówi się nawet: schizofreniczna. Schizofreniczność świata i postaci, o której pisać należy w cudzysłowie, nie ma tu jednak nic z nieświadomości stanu chorobowego. Nie jest bowiem tak, że człowiek - zupełnie tego nieświadomy - ulega z konieczności raz jednej, raz drugiej formie osobowości, że uczestniczy raz w jednym, raz w drugim świecie, że - inaczej mówiąc - jest w posiadaniu jakichś zupełnie przewyższających go i niepojętych sił, które nim się bawią i grają, a ostatecznie toczą o niego zażartą walkę. Mówiąc krótko: bohaterowie Dostojewskiego, inaczej niż bohaterowie Flauberta, w pełni zdają sobie sprawę z wewnętrznych niekonsekwencji i rozbicia; nie biorą prawdy za fikcję i fikcji za prawdę, co najwyżej - „działając po wpływem jakiegoś huraganu chaotycznych uczuć” (Młodzik) - mają niekiedy trudność z szybkim rozpoznaniem i nazwaniem emocji ${ }^{16}$, co widać chociażby na przykładzie Raskolnikowa: „Nagle niespodziane uczucie ostrej nienawiści do Soni przeszyło mu serce. Zdziwiony i przerażony tym uczuciem, podniósł głowę i spojrzał na nią uważnie. Spotkał jej serdeczne, niespokojne i współczujące spojrzenie. To była miłość; jego nienawiść rozwiała się jak przywidzenie. A więc to było coś innego. Omylił się widocznie co do tego uczucia" ${ }^{17}$.

Antropologiczna ambiwalencja Dostojewskiego nie ma więc wiele wspólnego z taką czy inną wersją ontologicznego dualizmu. Szukając literackich paraleli, powiedzieć można raczej, że wizja człowieka u Dostojewskiego jest podobna do wizji człowieka u Sofoklesa, zawartej zwłaszcza w pierwszym stasimonie Antygony, który - jak pisze Barbara Skarga - „wywołuje w słuchającym wrażenie, że wszystko, co można było powiedzieć o człowieku, już, w niej właśnie, zostało powiedziane"18. Dla Sofoklesa człowiek to deinos, co w polskim przekładzie oddane jest za pomocą słowa „dziwny”: „Siła jest dziwów, lecz nad wszystkie sięga / Dziwy człowieka potęga"19. Tak, człowiek jest dziwny, lecz deinos

16 Por. A. Gide, Dostojewski, dz. cyt., s. 142.

17 F. Dostojewski, Zbrodnia i kara, tł. J. P. Zajączkowski, Warszawa, s. 482.

18 B. Skarga, Ślad i obecność, Warszawa 2002, s. 203.

19 Sofokles, Antygona, w. 332, s. 101, [w:] tegoż, Tragedie, tł. K. Morawski, opr. Z. Kubiak, Warszawa 1969. 
oznacza także „straszny”, „potężny”, „biegły” i „umiejętny”, a nawet „niesamowity”20, co istotnie pogłębia rozumienie Sofoklesowej teorii człowieka. Określenia pozytywne krzyżują się tu z negatywnymi, wartościujące dodatnio $\mathrm{z}$ deprecjonującymi. Istota ludzka nie jest monolitem, przeciwnie: jest złożona, wielowarstwowa i poplątana, wewnętrznie sprzeczna i niekonsekwentna. Mówiąc precyzyjniej: jest ontologicznie pęknięta; postulowaną jedność człowieka uniemożliwiają zbyt liczne rysy wyraźnych aporii.

\section{Prawosławie i egzystencjalizm}

Czy jednak i ta analogia nie jest zbyt przesadzona? Czy starożytna Grecja i prawosławna Rosja są rzeczywiście tak blisko siebie? Czy niejednoznaczność ludzkiej natury i jej tajemniczość może oznaczać to samo zarówno u Sofoklesa, jak i u Dostojewskiego? Czy „pęknięcie”, o którym tu mowa, ma dla rosyjskiego pisarza również tak mocne ontologiczne znaczenie i czy - wracając do zadanego wcześniej już pytania - różnorodność tkwiąca w człowieku może zostać zintegrowana w jednej osobie?

Dostojewski odpowiedziałby mniej więcej tak: Wielowarstwowość ludzkiej psyche jest nie do przezwyciężenia dla myśli dyskursywnej. Człowiek, jako tajemnica, musi być rozpatrywany w perspektywie biblijnej, a nie - naukowej; nadmierny intelektualizm prowadzi bowiem na manowce, o czym z siłą nieznoszącą wątpliwości przekonują kolejni bohaterowie: Raskolnikow, Iwan Karamazow, Stawrogin.

Ten swoisty antyintelektualizm Dostojewskiego (przesadnie podkreślany przez Szestowa ${ }^{21}$ ) nie powinien dziwić, jeżeli weźmie się pod uwagę klimat wschodniego chrześcijaństwa, z którego rosyjski pisarz wyrasta. Patriarcha Konstantynopola, św. Focjusz pisze: „Bóg w swej Przedwiecznej Radzie zdecydował się wszczepić człowiekowi logos, aby w samej swojej ludzkiej strukturze stanowił uderzającą zagadkę

20 Por. B. Skarga, Ślad i obecność, dz. cyt. 204-205.

${ }_{21} \quad$ Zob. L. Szestow, Dostojewski i Nietsche. Filozofia tragedii, tł. C. Wodziński, Warszawa 1987. 
teologiczną"22. Teologia apofatyczna jest jednocześnie apofatyczną antropologią, każda więc próba racjonalizacji tajemnicy człowieka natychmiast ją zafałszowuje i niszczy ${ }^{23}$. Czym jednak jest tajemnica? Zgodnie z dystynkcjami Gabriela Marcela jest przede wszystkim czymś innym niż problem. Problem jest rodzajem intelektualnej zagadki i jako taki stanowi przedmiot badania naukowego, tajemnica jest zaś związana z egzystencją, nie podlega badaniu i nigdy nie można jej do końca rozświetlić, gdyż jednostka jest w nią całkowicie uwikłana: „Problemem jest to coś, co spotykam i co zagradza mi drogę, co jest w całości przede mną. Tajemnicą jest to coś, w co jestem zaangażowany" ${ }^{24}$.

Człowiek jest zaangażowany we własne życie, w myśli, uczucia, tęsknoty i pragnienia, niepokoje i lęki, radości i nadzieje: książę Myszkin jest rozdarty między Nastazją Filipowną i Agłają, Nastazja Filipowna między księciem Myszkinem a Rogożynem, Sonia, chcąc ratować rodzinę, godzi się na prostytucję, Alosza opuszcza monastyr, Raskolnikow nie umie unieść ciężaru zbrodni, choć logicznie biorąc, postąpił słusznie... Wszystko to stanowi zagadkę bytu i jako takie mieści się w ludzkim sercu, które zgodnie z wykładnią biblijną jest miejscem łączącym jego duchowe władze. „Głębia serca jest niedosiężna” - pisze Evdokimow, dodając od razu, że choć każdy posiada pewną wiedzę o sobie, to ona nigdy nie jest ostateczna i wyczerpująca, nie jest też miarą mego najgłębszego „Ja”, które przekracza wszelkie swoje zewnętrzne przejawy: „Świadomość jest ograniczona swoim własny wymiarem, którego nigdy nie można przekroczyć. Moje uczucia, myśli, działanie, świadomość należą do mnie, są «moje»; dlatego jestem ich świadomy, lecz «ja» jest ponad tym, co jest «moje»" 25 .

To, co „nie moje we mnie”, daje się określić u Dostojewskiego właśnie jako boski porządek serca, w którym tkwi ziarno transcendencji, lub inaczej: jako głos sumienia, który upomina się o zachowanie wewnętrznego

22 Cyt. za: P. Evdokimov, Kobieta i zbawienie świata, tłum E. Wolicka, Poznań 1991, s. 41.

23 Por. tamże, s. 54.

24 G. Marcel, Od sprzeciwu do wezwania, tł. P. Lubicz, Warszawa 1984, s. 173.

25 P. Evdokimov, Prawosławie, tł. J. Klinger, Warszawa 2003, s. 72. 
aksjologicznego ładu. Jeśli więc Iwan Karamazow dostaje obłędu, to dostaje go z powodu niemożności uniesienia świadomości zbrodni, której jest współwinien - mimo że racjonalne argumenty stoją po jego stronie. Jeśli Stawrogin wiesza się na strychu, to czyni to, bo nie może żyć w poczuciu niegodziwości i okrucieństwa, których się dopuścił - mimo że jego nihilizm zdawał się mocno zaimpregnowany na głos upominających się wartości. Jeśli Raskolnikow w malignie i obłędzie włóczy się po Petersburgu i ostatecznie przyznaje się do morderstwa starej lichwiarki, to zachowuje się tak, gdyż ciężar wyrzutów sumienia niczym stutonowy głaz po prostu go miażdży - mimo że "filozofia zbrodni”, którą opracował, była spójna i stała w sposób oczywisty po stronie idei postępu. Tak oto na przekór logice i intelektualnej spekulacji z głębi tajemnic ludzkiego serca odzywa się głos, którego zagłuszyć nie sposób. Zresztą, ten głos nie pojawia się nigdy wbrew ludzkiej woli - to ludzka wola go przywołuje, wyrażając tym samym ów skomplikowany kompleks sprzecznych pragnień, niezrozumiałą symultaniczność przeciwbieżnych dążeń. Kto za tym głosem pójdzie, swe życie ocali (Raskolnikow), kto się mu sprzeciwi - przegra (Stawrogin, Iwan Karamazow).

Głos, o którym tu mówimy, unaocznia, że człowieka nie można zamknąć w skończone ramy definicji: człowiek - homo viator - nie tyle stoi pośród świata, ile poprzez ten świat idzie. Głos jest bowiem przywoływany nieustannie i nieustannie domaga się odpowiedzi, a miara tych odpowiedzi określa każdorazowo odpowiadającego. Raskolnikow zabił, lecz czy może być zdefiniowany jako morderca, skoro zakończenie powieści ukazuje nam rozpoczęty proces jego duchowego odradzania się? Dymitr Karamazow jest ukazany jako lubieżnik, lecz czy jego niepohamowana namiętność nie jest jedynie nieumiejętnością kochania, bezradnością dziecka, które samo miłości nie doświadczyło? Zawiłe drogi ludzkich myśli i decyzji nie pozwalają na jednoznaczne określenia. Filozofia egzystencji mówi tyle: osoba nie jest, lecz staje się, jej istotę stanowi bowiem przekraczanie siebie. Sartre wyraził to poprzez znaną formułę „egzystencja poprzedza esencję" ${ }^{26}$, Marcel - mówiąc, że dewizą osoby 
„jest nie sum, ale sursum”27, a Ricoeur - definiując ją poprzez dialektykę pojęć idem (substancjalność, identyczność) i ipse (teleologia, tożsamość $)^{28}$.

Myśl prawosławna idzie tu podobną ścieżką: osoba to jednocześnie prósopon i hypóstasis ${ }^{29}$. Pierwsze określenie oznacza psychologiczny aspekt bytu zwróconego w stronę własnego świata wewnętrznego po to, by przyswajać i scalać te elementy, których jest nosicielem. Określenie drugie wskazuje na bytową otwartość, przekraczanie siebie i transcendencję ku Drugiemu. Sama bowiem etymologia słowa „osoba” oznacza pierwotnie maskę, jaką nakładali aktorzy w tragedii greckiej ${ }^{30}$. „Osoba” wskazuje więc na uczestnictwo i bytową partycypację, ontologiczną zależność i brak autonomii, konieczność dopełnienia struktury ludzkiej o jakiś transcendentny porządek.

Jeśli więc Dymitr Karamazow mówi, że zakochany lubieżnik jest gotowy wszystko oddać za kobietę („odda za nią własne dzieci, ojca sprzeda i matkę, Rosję i ojczyznę; będąc uczciwym, pójdzie i ukradnie; będąc łagodnym - zarżnie; wiernym będąc - zdradzi" ${ }^{31}$ ), to Dostojewski chce przez to powiedzieć, że niepohamowany tygiel kipiących namiętności, któremu zaprzeczyć nie sposób, powinien nie tyle zostać unicestwiony, co raczej przejść metanoię i jako taki kierować się w stronę wartości. I rzeczywiście, pełen namiętności Dymitr wyrywa się z matni hedonizmu, zwraca się w stronę Boga i, nie tracąc jednak nic ze swej namiętnej natury, wykrzykuje: „[...] znów odrodzimy się ku radości. [...] Boże, niech omdlewa człowiek w modlitwie! [...] I wówczas my, ludzie podziemni, zaśpiewamy z głębi ziemi tragiczny hymn do Boga, który żyje radością! Niech będzie pochwalony Bóg i Jego radość! Miłuję Go!"’22.

Ergo: osoba jest nosicielem tego wszystkiego, co bytowi ludzkiemu przysługuje i poprzez co byt ludzki żyje. Biblijny personalizm mówi

\footnotetext{
27 G. Marcel, Homo Viator, tł. P. Lubicz, Warszawa 1959, s. 28.

28 P. Ricoeur, O sobie samym jako innym, tł. B. Chełstowski, Warszawa 2005.

29 Zob. P. Evdokimov, Prawosławie, dz. cyt., s. 74-75.

30 Zob. A. Podsiad, Słownik terminów i pojęć filozoficznych, Warszawa 2000.

31 F. Dostojewski, Bracia Karamazow, dz. cyt., t. 1, s. 112.

32 Tamże, t. 2, s. 350.
} 
jednak wyraźnie o „normatywnym porządku natury”, który upomina się, by wszystkie elementy ludzkiej egzystencji były wypełnione i zintegrowane pneumatyczną (tj. pochodzącą od Ducha Świętego) zasadą osobowości, która działa w „, apofatycznej głębi serca”" ${ }^{33}$. Nie chodzi więc o to, by wielości zaprzeczyć, lecz by wielość tę scalić, a jej energię skierować w stronę dobra. Nie chodzi o to, by odrzucać uczucia i emocje, namiętności i pragnienia, a nawet żądze - chodzi o to, by zmienić ich kierunkowy wektor. Prawosławie poucza, że człowiek został stworzony na obraz i podobieństwo Boga i stąd „stan rajski”, a nie grzech, ostatecznie definiuje byt człowieka. Wielość staje się jednością poprzez Duch Świętego, a zło, z jakim mamy do czynienia, ma charakter etyczny, nie ontologiczny, gdyż ludzka natura z istoty, jako dzieło Boga, jest dobra ${ }^{34}$.

\section{Integralność}

Czy Dostojewski rzeczywiście podpisałby się pod tak idealistycznie brzmiącymi tezami, skoro jego świat przedstawia się zgoła nieewangelicznie? Czy Chrystus jest tu prawdziwą miarą człowieczeństwa, skoro tak trudno Go odnaleźć na kartach powieści? Czy chrześcijańska epifania stanowi punkt wyjścia do poszukiwania odpowiedzi na „przeklęte problemy” człowieka, skoro świat nihilistycznych antywartości wydaje się naturalnym środowiskiem bohaterów? Gdzie jest światło Ewangelii, jeśli świat Dostojewskiego jest zanurzony w mroku nieprawości? Gdzie jest oczyszczenie i zbawienie, jeśli tak wiele jest tu pogubienia, psychicznych chorób, niesprawiedliwości, krzywdy, poniżenia, biedy, okrucieństwa, autodestrukcji, zazdrości, zbrodni, morderstw i samobójstw?

Antropologia Dostojewskiego, którą próbujemy tu zrekonstruować, jest chrystocentryczna. Rzeczywista trudność takiej konstatacji polega jednak na tym, że Dostojewski nie jest rzecznikiem jednej obowiązującej ideologii i jako taki nie stoi po stronie tryumfującej prawdy, lecz pokornego poszukiwania. Piętrzą się tu pytania, dochodzą do głosu liczne

33 Por. P. Evdokimov, Prawosławie, dz. cyt., s. 72.

34 Por. tenże, Kobieta i zbawienie świata, dz. cyt., s. 49. 
niepewności, pragnienie prawdy napotyka mur aporii. Wiara Dostojewskiego jest wiarą wątpiącą; jest poszukiwaniem, konfrontacją, wysiłkiem i walką; jest koniecznością zstąpienia do otchłani. Taka wiara nie ma nic wspólnego $\mathrm{z}$ duchowym banałem, który interesuje się jedynie szybkim pocieszeniem. Dostojewski rozumie bowiem zbyt dobrze złożoność ludzkiego ducha. Głębia serca, z której dochodzi głos Boga, jest także głębią ciemności: tu kryje się zło i tajemnica ludzkiej nieprawości. Otaczający świat, w którym odnajdujemy ślad Stwórcy, jest także pełen śladów diabła: tu przecież jeden drugiego pożera. Kto tego nie chce widzieć, instrumentalizuje religię: odarta z sacrum staje się wówczas zwykłą pigułką przeciwbólową.

Powieści Dostojewskiego zamknięte są w horyzoncie ewangelicznym, Chrystus jest miarą człowieczeństwa, prawosławie jest odpowiedzią na antropologiczną kwestię tajemnicy i ambiwalencji. Ewangeliczny horyzont jest jednak nienachalny, Chrystus jest Bogiem ukrytym, a prawosławie unika intelektualnej spekulacji. Bóg daje się odnaleźć pośród ciemności grzechów i biedy ludzkiej, pośród mroków pychy i niewiary, w nocy zwątpienia i występku ${ }^{35}$. „W moim pokoju przed obrazem zapala się zawsze na noc lampkę - oznajmia Hipolit Terentiew - światło jest blade i nikłe, wszystko jednak można przy nim rozpoznać" ${ }^{36}$. Blade światło świecy przy ikonie ledwo tylko rozświetla głęboką czerń nocy - lecz jednak czyni to. Podobnie światło wiary u Dostojewskiego: lekko rozprasza ciemność, choć nie eliminuje jej zupełnie, jest delikatne, zawsze dyskretne niczym mała lampka przy świętym obrazku, otoczone ciemnością, postawione $\mathrm{z}$ boku, niemal gdzieś $\mathrm{w}$ kącie, ledwo się tli, lecz jednak tli się odważnie wobec swej potężnej antytezy. „Ikona Chrystusa, którą Dostojewski ustawia w mroku chaosu, buty i cynizmu humanizmów ateistycznych, ukazuje Boga, który nie jest ani konkwistadorem, ani bohaterem. Potęga, triumf, walka - te militarne kategorie są tu nieobecne"37. 
Z tego też względu pośród nieczułości i okrucieństwa świata, naprzeciw bezwzględnych egoistów i cyników stawia Dostojewski księcia Myszkina - symbol samego Chrystusa. Cichy, skromny, wręcz nieśmiały, wrażliwy i współczujący, prostolinijny, szczery i otwarty, pragnący dobra i sprawiedliwości, zgody i pojednania, kochający dzieci, pełen empatii dla chorych, rozumiejący upadłych, naiwny w swej wierze w dobro człowieka, miłujący całą ludzkość. Jest inny. Nie wpisuje się w normy egoistycznego społeczeństwa. Dlatego uznawany jest za idiotę. Jak pisze Grossman: „W tej jaskini, gdzie panuje zysk, oszustwo, kult pieniądza i pogarda dla człowieka, wszyscy ludzi uczciwi i czyści duchem skazani są na zatratę" 38 .

Być może właśnie duchowy portret Myszkina daje nam najlepszą odpowiedź na pytanie o nieoczywistą obecność Boga u Dostojewskiego. Jeśli bowiem jest to "Chrystus w ukryciu”, który nie walczy na argumenty, lecz objawia się pośród ludzkiej nędzy, to symbolizujący tego Chrystusa Myszkin potwierdza to sugestywnie. Widać to w ostatniej niezwykle przejmującej scenie Idioty, kiedy książę Myszkin i Parfien Rogożyn czuwają przy zwłokach Nastazji Filipowny. Myszkin drży i pyta: „Tyś ją zabił?”. „Nożem?”. „Tak” - odpowiada Rogożyn - „tak, można powiedzieć, jakby na półtora... albo nawet na dwa werszki wszedł ten nóż... w samiutką lewą pierś... a krwi, można powiedzieć, najwyżej z pół stołowej łyżki wyciekło na koszulę; więcej nie było..."39. Potem Rogożyn zaczyna krzyczeć, wybucha śmiechem i nagle - milknie. Potem, co jakiś czas, niczym w malignie, znów wykrzykuje, głośno i ostro mówi coś, co zupełnie nie ma sensu, znowu milknie, potem śmieje się, mamrocze. Siedząc obok mordercy Myszkin wyciąga drżącą rękę, głaszcze głowę, włosy, policzki; mija noc, robi się dzień; dojmujący smutek przygniata mu serce, drży, płacze, przytula swoją zapłakaną twarz do bladej twarzy Rogożyna. „Kiedy po wielu godzinach drzwi się otworzyły i weszli ludzie, zastali mordercę zupełnie nieprzytomnego i w gorączce. Książę siedział przy nim bez ruchu na posłaniu i za każdy razem, kiedy chory

38 L. Grossman, Dostojewski, tł. S. Pollak, Warszawa 1968, s. 381.

39 F. Dostojewski, Idiota, dz. cyt., s. 688. 
wybuchał krzykiem albo bredził, śpiesznie przesuwał rękę po jego włosach i policzkach, jakby go pieszcząc i uciszając"

Nie ma wyroku potępienia. Nie ma odrzucenia. Jest prosty, lecz wymowny gest współczucia i troski. Tajemnica nieprawości nie będzie zaś wyjaśniana w naukowych dysputach, teologicznych rostrząsaniach i filozoficznych argumentach. Nie chodzi o teorię - chodzi o to, by jątrzące się rany grzesznika ktoś zgodził się opatrzyć.

I jeszcze jedna kwestia, znana, lecz warta przypomnienia z uwagi na bezpośrednie powiązanie $\mathrm{z}$ interesującymi nas tu kategoriami ambiwalencji, tajemnicy i ludzkiej integralności. Symbolika postaci Myszkina usytuowana jest w powieści obok symboliki Nastazji Filipowny Baraszkowej. Imię „Nastazja” wywodzi się od greckiego anastasis, czyli zmartwychwstanie, nazwisko Baraszkowa - od rosyjskiego baraszek, czyli baranek. Semantyczna analiza członów nazwiska bohaterki wskazywać ma samą esencję antropologii Dostojewskiego: dusza ludzka pełna wewnętrznych sprzeczności, niezgody i ambiwalencji, odzyskuje jedność, tj. zmartwychwstaje do pełnego życia w odkupieńczej misji Baranka ${ }^{41}$.

\section{Bibliografia}

Bachtin M., Problemy poetyki Dostojewskiego, tł. N. Modzelewska, Warszawa 1970.

Bierdiajew M., Rosyjska idea, tt. JC-SW, Warszawa 1987.

Dostojewski F., Biesy, tł. A. Pomorski, Kraków 2010.

Dostojewski F., Bracia Karamazow, tł. A. Wat, Wrocław 1995.

Dostojewski F., Idiota, tł. J. Jędrzejewicz, Warszawa 1997.

Dostojewski F., Zbrodnia i kara, tł. J. P. Zajączkowski, Warszawa.

Evdokimov P., Kobieta i zbawienie świata, tłum E. Wolicka, Poznań 1991.

$40 \quad$ Tamże, s. 690.

${ }_{41}$ Por. E. Mikiciuk, „Chrystus w grobie” i rzeczywistość Anastasis. O symbolice grobowej w „Idiocie” Fiodora Dostojewskiego, „Znak” 1999 nr 10 (533), s. 122-125; D. Jastrząb, Duchowy świat Dostojewskiego, dz. cyt., s. 46. 
Evdokimov P., Prawosławie, tł. J. Klinger, Warszawa 2003.

Gide A., Dostojewski, tł. K. Kot, Warszawa 2003.

Grossman L., Dostojewski, tł. S. Pollak, Warszawa 1968.

Hesse H., Wilk stepowy, tł. G. Mycielska, Warszawa 1999.

Jastrząb D., Duchowy świat Dostojewskiego, Kraków 2009.

Mackiewicz-Cat S., Dostojewski, Bielsko Biała 1997.

Marcel G., Homo Viator, tł. P. Lubicz, Warszawa 1959.

Marcel G., Od sprzeciwu do wezwania, tł. P. Lubicz, Warszawa 1984.

Mikiciuk E., „Chrystus w grobie” i rzeczywistość Anastasis. O symbolice grobowej w „Idiocie” Fiodora Dostojewskiego, „Znak” 1999 nr 10 (533).

Pamuk O., Pisarz naiwny i sentymentalny, tł. T. Kunz, Kraków 2012.

Podsiad A., Stownik terminów i pojęć filozoficznych, Warszawa 2000.

Ricoeur P., O sobie samym jako innym, tł. B. Chełstowski, Warszawa 2005.

Sartre S.-P., Egzystencjalizm jest humanizmem, tł. J. Krajewski, Warszawa 1998.

Skarga B., Ślad i obecność, Warszawa 2002.

Sofokles, Antygona, w. 332, s. 101, [w:] tegoż, Tragedie, tł. K. Morawski, opr. Z. Kubiak, Warszawa 1969.

Szestow L., Dostojewski i Nietsche. Filozofia tragedii, tł. C. Wodziński, Warszawa 1987. 